\title{
Book Erratum to the Compendium of Inflammatory Diseases
}

\author{
Michael J. Parnham (ed.)
}

DOI 10.1007/978-3-7643-8550-7, (C) Springer International Publishing AG 2016

By mistake the book was published under the trade name of Birkhäuser. The correct imprint is Springer.

As the publisher Springer Basel merged with Springer International Publishing AG, the copyright in the work shall be vested in (C) Springer International Publishing AG 2016.

This Springer imprint is published by Springer Nature

The registered company is Springer International Publishing AG

The registered company address is: Gewerbestrasse 11, 6330 Cham, Switzerland

The updated online version of the original book can be found under DOI 10.1007/978-3-7643-8550-7 